\title{
Micro-Raman Studies of Li Doped and Undoped ZnO Needle Crystals
}

\author{
R. Jothilakshmi \\ Department of Physics, \\ Vel Tech University, \\ India
}

\section{Introduction}

The interest in $\mathrm{ZnO}$ structures has increased drastically in recent years as it is a wide band gap (3.4 ev) II-VI compound semiconductor, with a stable wurtzite structure with lattice spacing $\mathrm{a}=0.325$ and $\mathrm{c}=0.521 \mathrm{~nm}$. A prominent feature of $\mathrm{ZnO}$ is its large exciton binding energy $(\sim 60 \mathrm{mev})$ at room temperature which results in extreme stability of exciton [Khan,2005]. ZnO has been used as transparent conductors in solar cells, UV light emitters, as components in high power electronics and gas and chemical sensors. $\mathrm{ZnO}$ nanostructure has attracted attention for possible applications in optoelectronic and spintronic devices, such as high-emitting and laser diodes with polarized output, spin based memory and logic [Vladimir,2006].

The topic of p-doping is especially difficult and undoped $\mathrm{ZnO}$ exhibits n-type conductivity, and resists being doped p-type. This technological issue pulls up the use of $\mathrm{ZnO}$ for optoelectronics. p-type $\mathrm{ZnO}$ can be hypothetically achieved by doping with either Group-I or Group-V elements. Doping with Group-I elements is possibly more effective than doping with Group-V elements because of more shallow acceptors[Yamomoto,1999].It was observed that doping with Group-I elements increases donor concentration. This is attributed to tendency of Group-I dopants to occupy the interstitial sites, partly due to their small atomic radii [Park ,2002].The Group-V elements have low solubility in ZnO due to the mismatch in ionic radii. Several works on p-type $\mathrm{ZnO}$ doping have been made and however the results are not reproducible or questionable [Look ,2002, Look,2004].

It is believed that large difference in ionic radii between the host $\mathrm{Zn}(0.74 \AA)$ and the dopant $\mathrm{Li}(0.60 \AA)$ is very important for the appearance of Ferro electricity in Li-doped $\mathrm{ZnO}$. The electrical resistivity due to carriers can be improved by the introduction of Li ions [Wang, 2003].The interstice impurity may result in lattice distortion. Therefore the resistivity of the $\mathrm{ZnO}$ sample will increase. If the annealing temperature is high, the oxygen vacancy increases which produces more electrons and hence the resistivity of $\mathrm{Li}$-doped $\mathrm{ZnO}$ decreases [Min-Rui,2005].

Raman spectroscopy is a non destructive characterization method of choice for many recent studies of the vibrational properties of $\mathrm{ZnO}$ nanostructures [Khan,2005, Vladimir,2006, Harish Kumar,2007]. In the present work we have carried out a comprehensive MicroRaman scattering study of the phonons in Li doped and undoped $\mathrm{ZnO}$ needle crystals have been grown using flux growth to ensure good quality and an effective incorporation of the 
dopant ions. Flux growth offers the convenience of operating under relatively low temperatures and also it is helpful to obtain crystals with more control on the stoichiometric properties, annealed at $800^{\circ} \mathrm{C}$ for 1 hour to enhance oxygen vacancy.

\section{Experimental}

Raman spectra were measured from Li doped and undoped $\mathrm{ZnO}$ needle crystals using a Dilor XY double spectrometer under $514.5 \mathrm{~nm}$ excitation from an $\mathrm{Ar}^{+}$laser. The samples were placed on a glass plate and the laser beam was focused onto the sample using a 50X objective lens. Before the spectra were recorded the instrument was calibrated using the Raman line of Si wafer. The total power of laser excitation at the sample was about $1.05 \mathrm{mw}$.

\section{Results and discussion}

$\mathrm{ZnO}$ is a semiconductor with wurtzite crystal structure, having the space group $\mathrm{c}_{6 \mathrm{v}}^{4}$ with two formula unit primitive cell, where all atoms occupy $C_{3 \mathrm{v}}$ sites [Roth,1967].The optical phonons at the $\Gamma$ point of the Brillouin zone belong to the following irreducible representation.

$$
\Gamma_{\text {opt }}=1 \mathrm{~A}_{1}+2 \mathrm{~B}_{1}+1 \mathrm{E}_{1}+2 \mathrm{E}_{2} .
$$

Both $\mathrm{A}_{1}$ and $\mathrm{E}_{1}$ modes are polar and split into transverse (TO) and longitudinal optical (LO) phonons, all being Raman and infrared active. The two non polar $\mathrm{E}_{2}$ modes having two wavenumbers, $E_{2}$ (high) is associated with oxygen atoms and $E_{2}$ (low) is associated with $\mathrm{Zn}$ sublattice. Both are Raman active only. The $B_{1}$ modes are infrared and Raman inactive that is they are silent modes [Khan,2005, Bundesmann,2003].

The measured micro-Raman spectra at an arbitrary point of needle $\mathrm{ZnO}$ crystal and $\mathrm{Li}$ doped needle crystal are shown in Figs. 1(a) and 1(b) respectively.

The wavenumbers of the Raman active phonon modes reported previously for bulk and needles crystals are presented in Table1. [Khan,2005, Tatjana,2007].

Comparison of Fig1 (a) with Table 1, shows that four fundamental and two second-order modes are observed. The only Raman active non polar $\mathrm{E}_{2}$ (high) mode associated with oxygen atom vibration appears at $437 \mathrm{~cm}^{-1}$ with appreciable intensity and $\mathrm{E}_{2}$ (low) associated with the heavy Zn sublattice is absent [Khan,2005, Alim,2005]. This fact explains that the low-frequency $E_{2}$ mode does not resonate at $E_{0}$. The vibration of the $\mathrm{Zn}$ sublattice does not modulate valence-band states of $\mathrm{ZnO}$ which compose almost exclusively of oxygen $2 \mathrm{p}$ wave functions [Calleja,1977]. $377 \mathrm{~cm}^{-1}$ corresponds to $\mathrm{A}_{1}$ (TO) and $\mathrm{E}_{1}(\mathrm{TO})$ mode at $410 \mathrm{~cm}^{-1}$ is not predominant in the spectra due to the chosen scattering geometry. A weak $\mathrm{E}_{1}(\mathrm{TO})$ band at $410 \mathrm{~cm}^{-1}$ will appear in the spectrum of the sample consisting of tripods which are not c-axis orientated and may be ascribed to the contribution of the polarization due to crystals mixed orientation [Gupta,2006].Thus the presence of a very weak band at $410 \mathrm{~cm}^{-1}$ corresponding to $\mathrm{E}_{1}(\mathrm{TO})$ mode indicates that $\mathrm{ZnO}$ needle crystals have not grown preferably c-axis perpendicular to the substrate [Tatjana,2007].A weak peak is observed at $582 \mathrm{~cm}^{-1}$. This band may be due to $A_{1}(\mathrm{LO})$ or $\mathrm{E}_{1}(\mathrm{LO})$ mode ( see Table 1 ). It is reported $\mathrm{E}_{1}(\mathrm{LO})$ can occur at 584 $\mathrm{cm}^{-1}$ as this mode is related to the defects such as oxygen vacancy or interstitial zinc in zinc oxides [Zhang,2006, Zhao,2006]. This is the reason for the appearance of a weak band at 582 $\mathrm{cm}^{-1}$ in our case. The $\mathrm{A}_{1}(\mathrm{LO})$ mode is not observed shows the absence of resonance of exciting phonon energy with that of electronic interband transition with in the $\mathrm{ZnO}$ particle [Rajalakshmi ,2000]. 


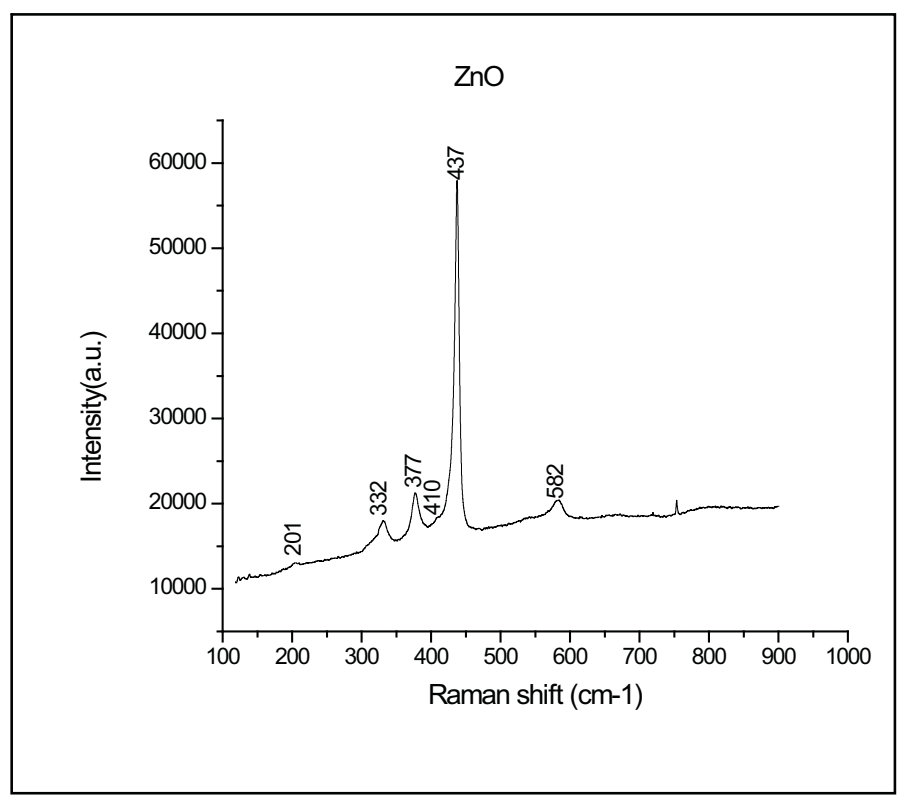

(a)

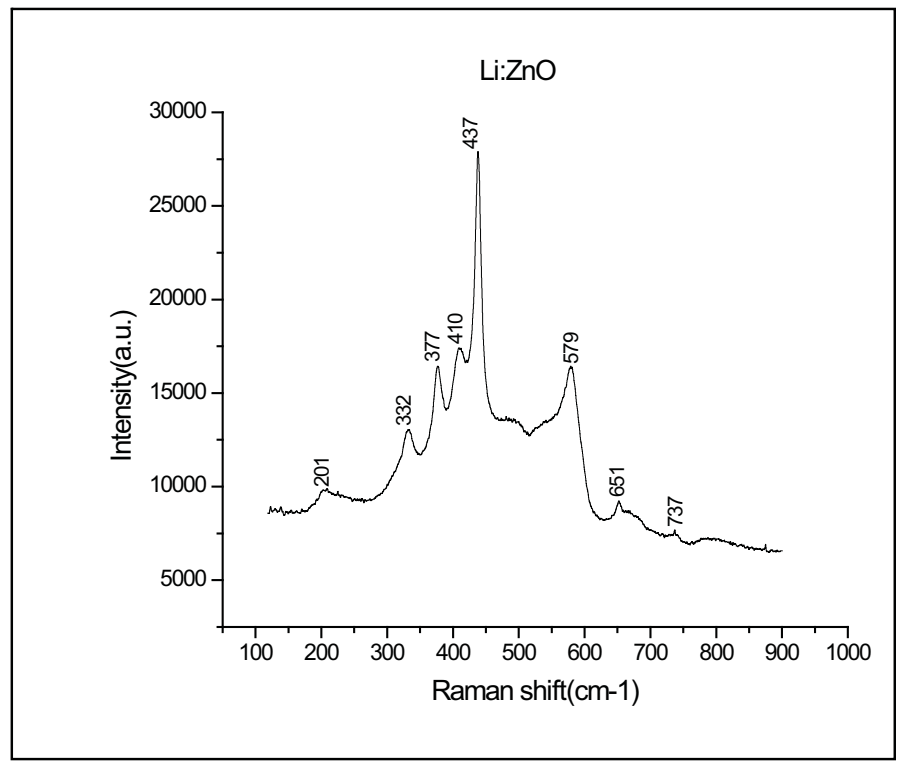

(b)

Fig. 1. (a) and (b) Micro-Raman spectra of $\mathrm{ZnO}$ and $\mathrm{Li}$ : $\mathrm{ZnO}$ needle crystal. 


\begin{tabular}{|c|c|c|}
\hline \multicolumn{2}{|c|}{ First Order } & Second Order \\
\hline Optical Phonon & $\begin{array}{c}\text { wavenumber } \\
\left(\mathrm{cm}^{-1}\right)\end{array}$ & $\begin{array}{c}\text { wavenumber } \\
\left(\mathrm{cm}^{-1}\right)\end{array}$ \\
\hline $\mathrm{E}_{2}($ low $)$ & 102 & 208 \\
\hline $\mathrm{A}_{1}(\mathrm{TO})$ & 379 & 334 \\
\hline $\mathrm{E}_{1}(\mathrm{TO})$ & 410 & $540-670$ \\
\hline $\mathrm{E}_{2}($ high $)$ & 439 & 986 \\
\hline $\mathrm{A}_{1}(\mathrm{LO})$ & 574 & 1050 \\
\hline $\mathrm{E}_{1}(\mathrm{LO})$ & 591 & $1084-1149$ \\
\hline
\end{tabular}

Table 1. Wavenumber and symmetry of the fundamental and second-order optical modes in $\mathrm{ZnO}$.

The peaks at about 201 and $332 \mathrm{~cm}^{-1}$ are attributed to the second-order Raman spectra arising from zone boundary phonons. [ Khan,2005, Tatjana,2007].The peak at $201 \mathrm{~cm}^{-1}$ corresponds to the wavenumber of $2 \mathrm{E}_{2}\left(101 \mathrm{~cm}^{-1}\right)$ at $\Gamma$. The peak at $332 \mathrm{~cm}^{-1}$ should be ascribed to two phonons from the K-M- $\Sigma$ around $160 \mathrm{~cm}^{-1}$ [Calleja ,1977]. These processes presumably occur for phonon wave vectors considerably removed from the center of the Brillouin zone. Without the knowledge of critical points and selection rules for various points in the zone, appropriate interpretation cannot be made [Tatjana,2007, Nusimovici,1965].

On comparison of Micro-Raman spectra of Li doped ZnO Fig.1 (b) with that of Fig.1 (a), it is noticed that in the case of undoped $\mathrm{ZnO}$ the intensity has been decreased. When $\mathrm{Li}$ atoms are introduced there will be a change in the electronic bonding force between the nearest two atoms. This in turn will influence the Raman peak positions and line profile. Moreover a drastic phonon anomaly feature was not observed in our case. Hence it suggests that the electronic effects are predominant than the ionic instability [Ehleeanul, 2002].

The $\mathrm{E}_{2}$ mode at $437 \mathrm{~cm}^{-1}$ of Li doped $\mathrm{ZnO}$ does not show the Li-dependence [Ehleeanul ,2002] as it is associated with oxygen atom vibration[Khan, 2005, Alim 2005].The second order mode at $201 \mathrm{~cm}^{-1}$ occurring due to oxygen vacancies is pronounced. The peaks at 332 and $377 \mathrm{~cm}^{-1}$ are same in both cases. The peak at $410 \mathrm{~cm}^{-1} \mathrm{E}_{1}$ (TO) mode is much intense than undoped crystal. This feature is expected where in the crystals are not grown preferably in c-axis perpendicular to the substrate. This is an evidence of the growth conditions imposed on the system. [Tatjana,2007]. The $\mathrm{E}_{1}$ (LO) mode is highly intense and broad but shifted to a lower wavenumber side $\left(579 \mathrm{~cm}^{-1}\right)$ confirms the point defect density. $\mathrm{E}_{1}$ (LO) mode is associated with lattice defects, such as oxygen vacancies and zinc interstitials $E_{1}$ (LO) mode increases after annealing, so it is possible that defect level such as oxygen vacancies was increased [Tak,2006]. The From fig.1 (b) the origin of two new peaks at 651 and $737 \mathrm{~cm}^{-1}$ is not well understood. These peaks could be associated with multiphonon processes [Tatjana, 2007] or unlisted weak plasma lines [Rajalakshmi,2000].

In the present work the micro-Raman spectra was recorded at three different positions (center, tip and wall) of the doped and undoped $\mathrm{ZnO}$ needle crystals. The plots are given in Fig.2 (a) and 2(b) 

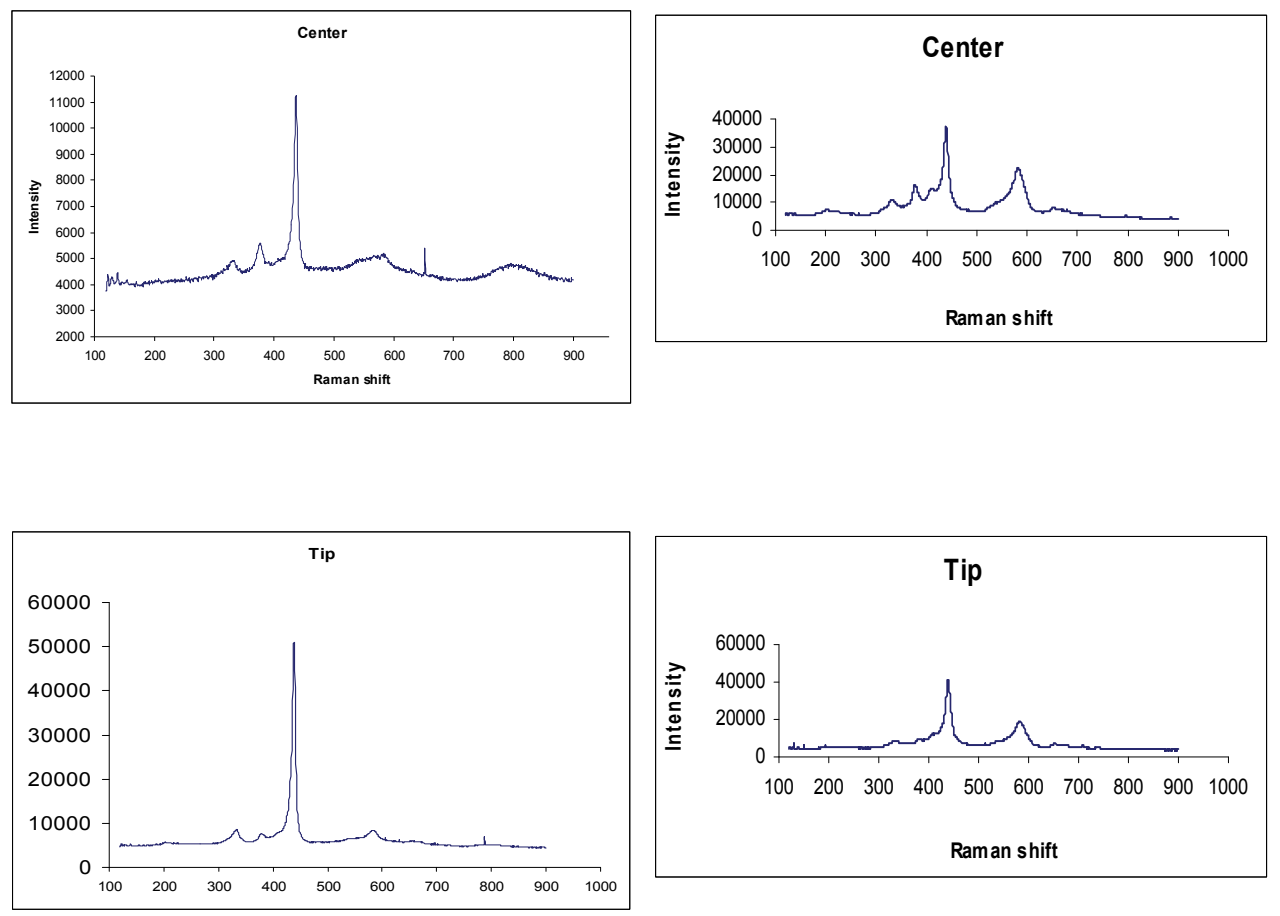

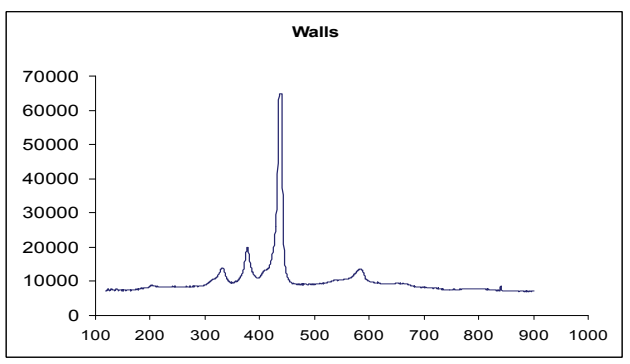

(a)

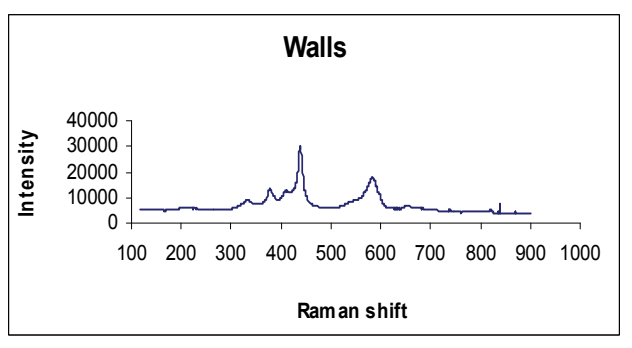

(b)

Fig. 2. (a) and (b) are plots of micro-Raman spectra of $\mathrm{ZnO}$ and $\mathrm{Li}: \mathrm{ZnO}$ at different position To study the quality of the crystal the strongest Raman active peak at $437 \mathrm{~cm}^{-1}$ was intensity normalized and a Gaussian fit was applied to get the area and width under each curve for different regions given in fig. 3(a) and 3(b). 

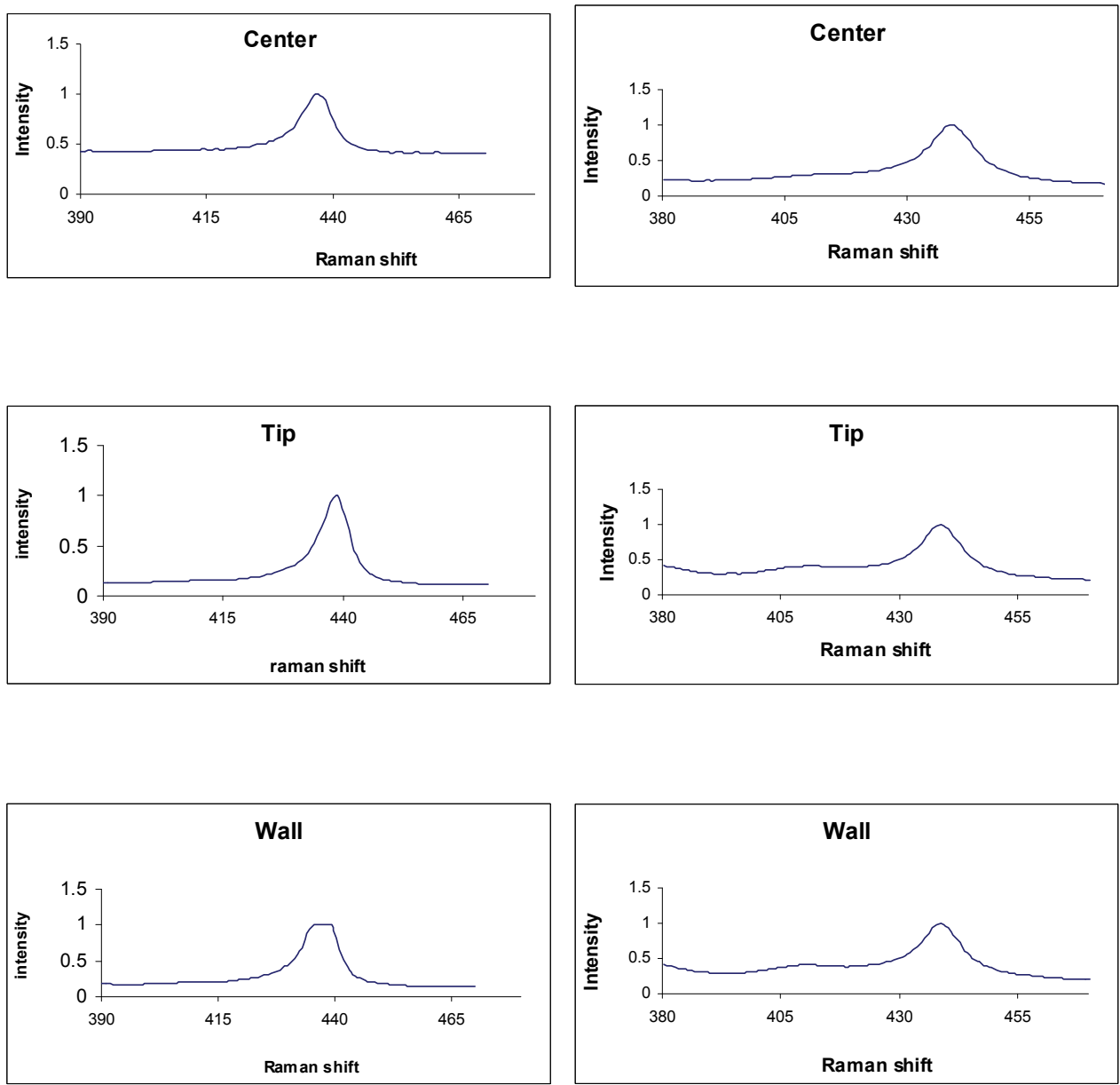

(a)

(b)

Fig. 3. (a) and (b). Intensity normalized $\mathrm{ZnO}$ and $\mathrm{Li}$ : $\mathrm{ZnO}$ peaks at various positions.

Line width and grain size are inversely proportional to each other [Harish Kumar,2007, Zhang, 2006]. When width decreases grain size increases, a good crystalinity is expected. Similarly area under the peak also shows the same feature as a sharp peak will be observed for a regular degree of structural order. Table 2. presents area and width at center, tip and wall of $\mathrm{ZnO}$ and Li doped $\mathrm{ZnO}$ needle crystals. On comparison of doped and undoped $\mathrm{ZnO}$ needle crystals, it is found that tip of the crystal shows a good crystallinity and high degree of structural order. 


\begin{tabular}{|c|c|c|c|c|}
\hline \multirow{2}{*}{} & \multicolumn{2}{|c|}{ ZnO needle crystal } & \multicolumn{2}{c|}{ Li doped ZnO needle crystal } \\
\cline { 2 - 5 } & Area $\left(\mathrm{cm}^{-2}\right)$ & Width $\left(\mathrm{cm}^{-1}\right)$ & Area $\left(\mathrm{cm}^{-2}\right)$ & Width $\left(\mathrm{cm}^{-1}\right)$ \\
\hline Center & 5.8 & 7.3 & 7.6 & 9.7 \\
\hline Tip & 5.0 & 7.2 & 7.4 & 9.6 \\
\hline Walls & 8.9 & 8.4 & 9.6 & 11.3 \\
\hline
\end{tabular}

Table 2. Area and Width of doped and undoped needle crystal at different positions

\section{Conclusions}

We have made a careful Micro-Raman study on $\mathrm{ZnO}$ and Li doped $\mathrm{ZnO}$ annealed needle crystals. It was found that $\mathrm{E}_{2}$ phonon mode of doped and undoped $\mathrm{ZnO}$ does not show any shift .But $\mathrm{E}_{1}(\mathrm{TO})$ mode is predominant and two new less intense peaks have been observed in Li doped crystal. The shift in the $\mathrm{E}_{1}(\mathrm{LO})$ mode to a lower wavenumber confirms that our material shows nano dimensional character. With the intensity normalized plots we can conclude that for both $\mathrm{Li}$ doped and undoped $\mathrm{ZnO}$ crystals the crystallinity is improving towards the tips of the needle crystals.

\section{Reference}

C. Bundesmann, N. Ashkenov, and M. Schubert, Appl. Phys. Lett. Vol. 83, No. 10, 8 September 2003.

J. M. Calleja, and M. Cardona, phys. Rev. B 16, 3753 (1977).

Ehleeanul Islam, J. Phys. Soc. Jpn. Vol. / No:71, page 1594, 2002.

V. Gupta, P. Blattacharya, Y. I. Yusuk, K. Sreenivas and R. S. Katiyar, J. Cryst. Growth 287, 39 (2006).

Harish Kumar Yadav and K. sreenivas Mater. Res. Soc. Symp. Proc. Vol. 957, 2007.

Khan A. Alim, J. Appl. Phys, 97, 124313(2005).

Khan A. Alim, Appl. Phys. Lett. 86, 053103(2005).

D. C. Look, D. C. Reynolds, C. W. Litton, R. L. Jones, D. B. Easer and G. Cantweel, Appl. Phyys. Lett. 81, 1830(2002).

D. C. Look, B. Claflin, Y. I Alivor and S. J. Park, Phys. Stat. Sol. (b) 241, 624(2004).

Min-Rui Wang. Journal of Material Science 40 (2005).

N. Nusimovici and J. L. Birman, Bull. Am. phys. Soc. 10, 616(1965).

C. H. Park, S. B. Zhang, and S. H. Wei, Phys. Rev. B66, 073 202(2002).

M. Rajalakshmi and A. K. Arora, J. Appl. Phys. Vol. 87. , No. 5, (2000).

W. L. Roth, in The Physics and chemistry of II-Vi compounds, edited by M. Aven and J. S.

Prener (north-Holland, Amsterdam, 1967), p. 122.

Tatjana Dedora, Mater. Res. Soc. Symp. Proc. Vol. 957, 2007.

Tak, Park, and yong, J. Vac. Sci. Technol. B, Vol. 24, No. 4, jul/Aug 2006.

Vladimir A. Fonoberov, J. Nanoelectron. optoelectron, 2006, vol-1, No. 1.

X. s. Wang , Appl. phys. A77, 561-565(2003).

T. Yamomoto and H. Kalayana-Yoshida, Jpn. J. Appl. Phys, 38, L166 (1999).

D. F. Zhang, L. D. Sun and C. H. Yan, Chem. Phys. Letters 422, 46(2006). 
A. ZhaoT. Luo, L. Chem, Y. Liu, X. Li, Q. Tang, P. Cai, Y. Qian, Mat. Chem. Phys. 99, 50(2006).

Y. Zhang, J. Phys. :condens. Matter 18(2006)957-963. 


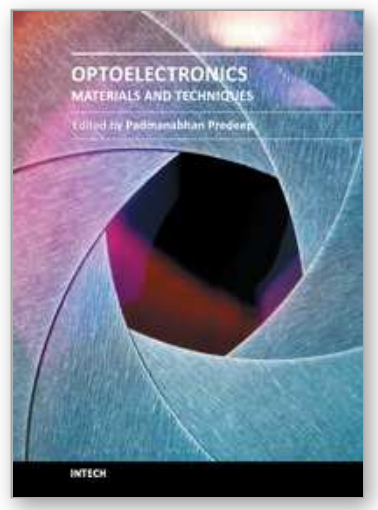

\author{
Optoelectronics - Materials and Techniques \\ Edited by Prof. P. Predeep
}

ISBN 978-953-307-276-0

Hard cover, 484 pages

Publisher InTech

Published online 26, September, 2011

Published in print edition September, 2011

Optoelectronics - Materials and Techniques is the first part of an edited anthology on the multifaceted areas of optoelectronics by a selected group of authors including promising novices to the experts in the field.

Photonics and optoelectronics are making an impact multiple times the semiconductor revolution made on the quality of our life. In telecommunication, entertainment devices, computational techniques, clean energy harvesting, medical instrumentation, materials and device characterization and scores of other areas of R\&D the science of optics and electronics get coupled by fine technology advances to make incredibly large strides. The technology of light has advanced to a stage where disciplines sans boundaries are finding it indispensable. Smart materials and devices are fast emerging and being tested and applications developed in an unimaginable pace and speed. Here has been made an attempt to capture some of the materials and techniques and underlying physical and technical phenomena that make such developments possible through some real time players in the field contributing their work and this is sure to make this collection of essays extremely useful to students and other stake holders such as researchers and materials scientists in the area of optoelectronics.

\title{
How to reference
}

In order to correctly reference this scholarly work, feel free to copy and paste the following:

R. Jothilakshmi (2011). Micro-Raman Studies of Li Doped and Undoped ZnO Needle Crystals, Optoelectronics - Materials and Techniques, Prof. P. Predeep (Ed.), ISBN: 978-953-307-276-0, InTech, Available from: http://www.intechopen.com/books/optoelectronics-materials-and-techniques/micro-raman-studies-of-li-dopedand-undoped-zno-needle-crystals

\section{INTECH}

open science | open minds

\section{InTech Europe}

University Campus STeP Ri

Slavka Krautzeka 83/A

51000 Rijeka, Croatia

Phone: +385 (51) 770447

Fax: +385 (51) 686166

www.intechopen.com

\section{InTech China}

Unit 405, Office Block, Hotel Equatorial Shanghai

No.65, Yan An Road (West), Shanghai, 200040, China 中国上海市延安西路65号上海国际贵都大饭店办公楼 405 单元

Phone: +86-21-62489820

Fax: $+86-21-62489821$ 
(C) 2011 The Author(s). Licensee IntechOpen. This chapter is distributed under the terms of the Creative Commons Attribution-NonCommercialShareAlike-3.0 License, which permits use, distribution and reproduction for non-commercial purposes, provided the original is properly cited and derivative works building on this content are distributed under the same license. 